\title{
Accounting Scandal Announcements: A Test Of Market Efficiency
}

Dana McLeod, Colorado College

Judith A. Laux, (E-mail: jlaux@ coloradocollege.edu), Colorado College

\begin{abstract}
This paper examines the hypothesis that the stock market overreacted to accounting scandals during 2002, resulting in extensive drops in share value followed by return reversals that reveal market inefficiencies. Data are gathered for nine firms directly involved in an accounting scandal, as well as the major competitors of those firms. An empirical test of returns for all thirtythree firms reveals that an investment strategy of selling short scandal firms and their competitors, followed by a contrarian investment strategy of buying those same stocks, resulted in risk-adjusted returns well above those expected for a period of one year after the scandal. These results reveal stock market inefficiencies and a potential to realize abnormal returns by capitalizing on investor overreaction.
\end{abstract}

\section{INTRODUCTION}

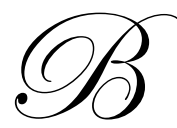

and Arthur Andersen.

the end of 2002, several of America's most successful businesses had been involved in some kind of accounting scandal and were being investigated by the Securities and Exchange Commission (SEC). Among these companies were WorldCom, Qwest, Xerox, Adelphia, Bristol-Myers Squibb,

The effects of misleading accounting are very detrimental to the securities world because knowledgeable investors often use fundamental analysis of a company's financial reports to determine if a stock is valued appropriately in the open market. Based on this analysis, people aim to buy undervalued stock and sell overvalued stock. During the accounting scandals of 2002, investors were suddenly faced with the prospect that financial statements may not accurately reflect the company's standing.

The purpose of this study is to discover whether the accounting scandals created market inefficiencies, thus challenging the Efficient Market Hypothesis. Furthermore, it investigates both contrarian investing and the Overreaction Hypothesis by constructing portfolios using various trading strategies and comparing their returns to expected risk-adjusted returns. The central question is: if investors are likely to panic in times of controversy, is it possible for a rational observer to make a quick profit from that mass exit from the market? When investors overreact to corporate scandals that receive massive media attention, their behavior will temporarily drive stock values below intrinsic value. If people over-generalize these same scandals, then investors will quickly sell shares of firms similar to the company tainted by the recent scandal, regardless of the financial standing of that company. The result will be that even the "good" company's market value will drop. A potential investment approach to these scandals is to sell short the scandal-tainted firm and the stock of the major competitors of that firm to benefit from the expected value drop. Another line of attack is a contrarian strategy, which aims to make a profit by going against what the majority of investors are doing. An outside spectator could buy stock in the "good" companies after their prices had fallen due to the scandal of the similar "bad" company. According to the Overreaction Hypothesis, the share value of the "good" company should revert back to its actual value relatively quickly, and the contrarian investor should be able to sell the stock for a quick profit.

The first part of the paper presents a summary of the literature related to the relevant theories, especially the Overreaction Hypothesis (ORH), the theory of contrarian investing, and the Efficient Market Hypothesis (EMH). 
The second half of the paper presents the empirical research, including two different strategies, a selling short strategy and a contrarian approach. An analysis of returns over set time intervals is performed for each strategy. Actual returns are compared to expected returns to determine whether it was possible to make better-than-expected profits using these trading techniques in the aftermath of the many scandals.

\section{A BRIEF REVIEW OF THE LITERATURE}

De Bondt and Thaler (1985) first proposed the concepts of the Overreaction Hypothesis (ORH) and the contrarian investment strategy. By studying monthly stock returns from 1926 to 1982 for firms traded on the New York Stock Exchange, the authors find that companies that previously under performed the market subsequently had returns higher than the market average. Based on this finding they form the contrarian investing strategy of buying losers and selling winners. Their research also shows that investors appear to overreact to unanticipated news events, temporarily affecting stock prices. This study undermines the Efficient Market Hypothesis by providing a trading strategy that claims to lead to above average returns and by giving evidence that stock prices do not always accurately reflect all public knowledge.

The concept of a price reversal is often seen as support for the ORH. Benou and Richie (2003), Hirschey (2003), and Forbes (1996) all support the existence of predictable price reversals. Many of these are based on the findings of De Bondt and Thaler (1985) that stocks that under perform the market will later provide above average returns. Benou and Richie examine several large firms whose stock has experienced a price decline of twenty percent or more during a single month. The study tests for price reversion, and the results support the idea that extreme price movements will eventually move back the other way. Many of the large firms used in the study experience positive and statistically significant abnormal returns in the first year following the twenty percent price drop. Benou and Richie claim that investor overreaction leads to the initial price drop, and they attribute the price reversal to a market correction meant to bring share value to a more appropriate level. They suggest that this information can be used to form a trading strategy where investors "can profit by buying the stocks of large firms that experienced large price declines and holding them six to 12 months following the decline" (p. 37).

Not all studies on overreaction find support for the theory. Conrad and Gultekin (1997) find that profits from a contrarian strategy are due to bid-ask errors in transactions costs. They conclude that measurement errors in previous studies have falsely given the impression of market inefficiency, resulting in the misleading impression that contrarian strategies provide above average returns. Conrad and Kaul (1993) perform a similar study testing for contrarian profits and market overreaction. They find no evidence of market overreaction with this study.

Despite the studies that contest the ORH and contrarian investing, the supporting evidence seems to be more extensive and more convincing and has huge implications for the Efficient Market Hypothesis. All three levels of the EMH assert that it is impossible to consistently realize above-normal profits in the stock market. The ORH claims that investor overreaction can be predicted when major, unexpected news events occur. A contrarian investor can then profit, time and again, from that overreaction by acting in a manner opposite to the majority. This strategy undercuts the validity of the EMH.

The Efficient Market Hypothesis enjoyed great popularity for many years, but evidence from the past several decades has begun to challenge the basic tenets of the theory. The EMH is currently considered by many to be "a highly simplified representation of the working of equity markets" (Dissaniake 1997, p. 45). The EMH does not leave any room for human error, assuming that all investors act completely rationally and that there is no way to find profits that haven't already been arbitraged away. Any time an investor is able to consistently beat the market and realize abnormal returns, the theory of efficient markets is contested. Although markets do appear to be relatively efficient, at times inefficiencies leave a temporary window to make abnormal profits. The current study investigates whether the accounting scandals represent one such window. 


\section{METHODOLOGY}

This study proposes that, in response to the many accounting scandals of 2002, investors became skittish about future scandals and pulled their money out of any stocks closely related to scandal-tainted firms, in particular major competitors of those firms. The hypothesis investigates whether the share value decrease was only short-term for the firms that had the scandal as well as for their competitors. If this is in fact market overreaction, then a return reversal should have quickly followed the initial value drop, revealing an opportunity for attentive investors to realize abnormal returns.

This paper tests two different strategies for capitalizing on scandal-related market overreaction. One strategy is to immediately sell short the stocks of scandal firms and their competitors. This will take advantage of the swift price fall that is predicted by the Overreaction Hypothesis (ORH). This study is unique in that it adds an element of over-generalization by examining competitors' shares as well as the actual scandal firm's value. The second strategy is a contrarian approach that involves buying scandal firms and their competitors when the price is low, one or two months following the scandal announcement, then holding the stocks until six months or one year after the scandal. According to the ORH, the share value should revert back to its appropriate market value soon after the overreaction. Actual returns will be based on the percentage change in closing stock prices from the designated buying date until the designated ending date. These returns will be compared to the Capital Asset Pricing Model's predicted return.

\section{DATA}

The nine scandal firms for this study were chosen from the CRS Report for Congress "Accounting Problems Reported in Major Companies since Enron." (Jickling 2003) The data are comprised of stock prices from various dates. The dates were based on the earliest announcement of an accounting scandal by the "scandal firm." Stocks selected include nine scandal firms and their major competitors, totaling thirty-three firms. A complete list of scandal firms, their major competitors, and the date of the initial scandal announcement can be found in Table 1.

Stock prices for each firm, as well as for the firm's competitors, were collected based on the date of the first announcement regarding accounting misconduct. Hoover's Online, which provides investment information and data for individual stocks, was used to determine the top competitors for each scandal firm.

\section{RESULTS AND ANALYSIS}

\section{Selling Short Strategy}

Table 2 shows an overall summary of the results for the short selling strategy. The top row includes the nine scandal firms only, and the bottom row is an average of all thirty-three stocks, both scandal firms and competitors. The results after one month show the return realized assuming the stock was sold short two trading days after the scandal announcement, and then bought back one month after the selling date. The two month returns are calculated by selling the borrowed stock two trading days after the announcement, and buying it back two months later. Next to each column of actual returns for one and two months is the corresponding expected return, as calculated by the CAPM.

Table 2 shows that returns were smaller for the two-month period, implying that the scandal firms experienced the greatest price drop during the first month; after that it appears that the share prices for these firms began to go back up. Overall, all thirty-three firms performed much better than the broader market, as did the scandal firms alone.

The CAPM expected returns are negative because the S\&P 500 fell throughout most of 2002-2003. Because none of the sample stocks' betas were negative, it is expected that the stocks will move in the same direction as the overall market: if the S\&P 500 goes down, the stocks can also be expected to go down. The negative expected returns make the actual positive returns even more significant. It should be mentioned that since the overall market fell, a positive return could have been realized by selling short a market index. However, the 
returns would have been minimal and smaller than the returns realized by selling short the scandal firms and their competitors.

Table 1 Scandal Firms, Top Competitors, and Announcement Date

\begin{tabular}{|c|c|c|}
\hline Scandal Firm & Top Competitors & Announcement Date \\
\hline Bristol-Myers Squibb Co. (BMY) & $\begin{array}{c}\text { Merck \& Co. Inc. (MRK) } \\
\text { Novartis AG (NVS) } \\
\text { Pfizer Inc. (PFE) } \\
\end{array}$ & July 11,2002 \\
\hline Dynegy Inc. (DYN) & $\begin{array}{c}\text { Duke Energy Corp. (DUK) } \\
\text { Exelon Corp. (EXC) } \\
\text { The Williams Companies Inc. (WMB) }\end{array}$ & May 9, 2002 \\
\hline Halliburton Co. (HAL) & $\begin{array}{c}\text { Baker Hughes Inc. (BHI) } \\
\text { Schlumberger Ltd. (SLB) } \\
\text { Technip (TKP) } \\
\end{array}$ & May 28,2002 \\
\hline $\begin{array}{l}\text { International Business } \\
\text { Machines Corp. (IBM) }\end{array}$ & $\begin{array}{c}\text { Electronic Data Systems Corp. (EDS) } \\
\text { Hewlett-Packard Co. (HPQ) } \\
\text { Microsoft Corp. (MSFT) }\end{array}$ & February 20, 2002 \\
\hline $\begin{array}{l}\text { Qwest Communications } \\
\text { International Inc. (Q) }\end{array}$ & $\begin{array}{c}\text { AT\&T Corp. (T) } \\
\text { Sprint FON Group (FON) }\end{array}$ & July 10, 2002 \\
\hline $\begin{array}{l}\text { The PNC Financial } \\
\text { Services Group (PNC) }\end{array}$ & $\begin{array}{l}\text { Mellon Financial Corp. (MEL) } \\
\text { National City Corp. (NCC) } \\
\text { Wachovia Corp. (WB) }\end{array}$ & July 18,2002 \\
\hline Time Warner Inc. (TWX) & $\begin{array}{c}\text { Viacom Inc. (VIA) } \\
\text { The Walt Disney Co. (DIS) } \\
\text { Yahoo Inc. (YHOO) }\end{array}$ & July 24,2002 \\
\hline Tyco International Ltd. (TYC) & $\begin{array}{c}\text { Johnson \& Johnson Inc. (JNJ) } \\
\text { Molex Inc. (MOLX) }\end{array}$ & January 22, 2002 \\
\hline Xerox Corp. (XRX) & $\begin{array}{c}\text { Canon Inc. (CAJ) } \\
\text { Hewlett-Packard Co. (HPQ) } \\
\end{array}$ & June 28,2002 \\
\hline
\end{tabular}

Table 2 Returns from Selling Short

\begin{tabular}{|l|c|c|c|c|}
\hline & $\begin{array}{c}\text { One Month } \\
\text { Return }\end{array}$ & $\begin{array}{c}\text { Monthly } \\
\text { CAPM }\end{array}$ & $\begin{array}{c}\text { Two Month } \\
\text { Return }\end{array}$ & $\begin{array}{c}\text { Two Month } \\
\text { CAPM }\end{array}$ \\
\hline Scandal Firms & $14.51 \%$ & $-0.38 \%$ & $6.6 \%$ & $-0.76 \%$ \\
\hline All Stocks & $8.38 \%$ & $-0.3 \%$ & $11.94 \%$ & $-0.6 \%$ \\
\hline
\end{tabular}

\section{Contrarian Strategy}

For the contrarian strategy of buying stocks after the scandal announcement (after share prices have presumably been sold off and driven lower), actual returns were computed for a holding period of six months and one year after the scandal. Two buy dates were tested in this strategy, one month after the scandal announcement and two months after. The CAPM return was based on the length of the holding period.

\section{Contrarian Approach - Buying One Month After Scandal Announcement}

The results for this approach are shown in Table 3. The scandal firms in the top row performed much better than expected, supporting the hypothesis that the scandal firms, which also realized positive returns in the selling short strategy, experienced a significant return reversal. This reversal was greatest during the first six months following the scandal, but returns, although diminishing, continued increasing over one year. The averages of the thirty-three firms also returned better-than-expected profits when compared to the CAPM. These results suggest that return reversal occurred for all firms, although it was greater for the scandal firms. 
Table 3 Returns from Contrarian Strategy, Buying One Month after Scandal Announcement

\begin{tabular}{|l|c|c|c|c|}
\hline & $\begin{array}{c}\text { Holding Until 6 Months } \\
\text { After Announcement }\end{array}$ & 5 month CAPM & $\begin{array}{c}\text { Holding Until 1 Year } \\
\text { After Announcement }\end{array}$ & 11 Month CAPM \\
\hline Scandal Firms & $36.27 \%$ & $-0.19 \%$ & $44.69 \%$ & $-0.42 \%$ \\
\hline All Stocks & $17.11 \%$ & $-1.5 \%$ & $25.8 \%$ & $-3.3 \%$ \\
\hline
\end{tabular}

\section{Contrarian Approach - Buying Two Months after Scandal Announcement}

The returns for the contrarian approach of buying the selected stocks two months after the scandal announcement, then holding them for six months and one year, are shown in Table 4. The scandal firms in the top row under-performed their CAPM for the holding period of six months and a buy date of two months after the announcement. However, this portfolio then produced better-than-expected profits over one year.

Table 4 Returns from Contrarian Strategy, Buying Two Months after Scandal Announcement

\begin{tabular}{|l|c|c|c|c|}
\hline & $\begin{array}{c}\text { Holding Until 6 Months } \\
\text { After Announcement }\end{array}$ & 4 month CAPM & $\begin{array}{c}\text { Holding Until 1 Year } \\
\text { After Announcement }\end{array}$ & 10 Month CAPM \\
\hline Scandal Firms & $-1.17 \%$ & $-1.5 \%$ & $15.28 \%$ & $-3.8 \%$ \\
\hline All Stocks & $7.47 \%$ & $-1.2 \%$ & $20.32 \%$ & $-3 \%$ \\
\hline
\end{tabular}

Finally, combining the selling short and contrarian approaches results in a very profitable trading strategy. Selling all thirty-three firms short for one month immediately following the initial scandal would have provided a return of $8.38 \%$. Then buying those same firms one month after the scandal announcement and holding them until one year after the announcement could have provided a $25.8 \%$ return. This combined strategy gives an annual return of $34.18 \%$, quite impressive compared to the expected annual return of $-3.6 \%$. If an investor were to deal only in scandal firms, since they are predicted to experience even greater price swings due to overreaction and return reversal, an annual return of 59.2\% was possible by selling the scandal stocks short for one month, then buying these stocks and holding for one year. This significantly exceeded the expected return of $-4.56 \%$.

It appears that, based on the raw data without removing any outliers, the market did overreact during the month immediately following the scandal announcement. Selling short scandal firms and their competitors provided positive returns during a bear market. Those firms appeared to reverse their price movement, and many of them experienced positive price changes over six months and one year following the scandal announcement. These results support the hypothesis proposed by this paper. Still, a couple of firms had very extreme price changes and these outliers may have skewed the returns. The same computations were performed without these firms, and the highlights of those tests are discussed in the following section.

\section{Adjusting for Outliers}

The cut-off point for outliers was determined to be a $75 \%$ price change at any time during the study period. This number is actually quite high for the average market, but since this test is studying investor overreaction, several high-volatility stocks, and an abnormal period in stock market history, this trigger point, though arbitrary, was deemed acceptable. A stock that showed a $75 \%$ price change for any one of the many calculations was removed from the data for all return periods, both before the $75 \%$ change as well as after it. Six stocks experienced a $75 \%$ or greater change.

Table 5 shows the returns from the two different strategies. Directly below the returns for the scandal firms and returns for all twenty-seven stocks are the CAPM expected returns for the corresponding time period. This chart shows that, although returns were smaller without the outliers, most of them were still greater than the expected riskadjusted return. 
Table 5 Returns Adjusted for Outliers

\begin{tabular}{|c|c|c|c|c|c|c|}
\hline & \multicolumn{2}{|c|}{ Selling Short } & \multicolumn{2}{|c|}{ Contrarian Strategy } & & \\
\hline & & & $\begin{array}{c}\text { Buy date } 1 \\
\text { month after } \\
\text { scandal } \\
\end{array}$ & & $\begin{array}{c}\text { Buy Date } 2 \\
\text { Months after } \\
\text { scandal }\end{array}$ & \\
\hline Holding Period & 1 Month & 2 Months & 6 Months & 1 Year & 6 Months & 1 Year \\
\hline Scandal Firms & $3.32 \%$ & $2.87 \%$ & $-7.35 \%$ & $8.59 \%$ & $0.73 \%$ & $8.65 \%$ \\
\hline CAPM For Scandal Firms & $-0.42 \%$ & $-0.83 \%$ & $-2.08 \%$ & $-4.58 \%$ & $-1.67 \%$ & $-4.17 \%$ \\
\hline Average of all 27 firms & $3.36 \%$ & $10.62 \%$ & $-0.67 \%$ & $7.39 \%$ & $-1.33 \%$ & $13.24 \%$ \\
\hline CAPM for all firms & $-0.28 \%$ & $-0.56 \%$ & $-1.39 \%$ & $-3.06 \%$ & $-1.11 \%$ & $-2.78 \%$ \\
\hline
\end{tabular}

\section{Selling Short}

Both the scandal firms alone and all twenty-seven firms together returned greater-than-expected profits with the selling short strategy. The returns for the scandal firms were greatest over the first month, which supports the results found in earlier sections. This implies that market overreaction to the scandal firms was greatest during the first month immediately following the scandal announcement. Interestingly, returns for all twenty-seven firms combined were much higher over a two-month selling short period. This may indicate that investors did not overreact immediately for the competitors of scandal firms, but instead hesitated, then sold off competitors' shares, driving prices down for a period of at least two months. Whatever the reason, the opportunity to realize abnormal profits by selling short scandal firms and their competitors did exist during 2002. Although profits were smaller without the outliers, the returns for the selling short strategy continued to support the hypothesis.

\section{Contrarian Strategy}

Results from the contrarian trading approach show that stock prices did experience a return reversal. This reversal was much more pronounced with a holding period until one year after the scandal than with a holding period through six months after, regardless of whether the stocks were bought one or two months following the announcement. Although returns were not as great once the study was adjusted for outliers, both showed more significant returns with a longer holding period. The scandal firms alone and the twenty-seven stocks together provided positive returns for a one-year holding period, but in both cases returns were negative over the six-month holding period. This indicates that share prices were still depressed after six months but began to rebound at some point between six months and one year after the scandal announcement.

Unfortunately, it is difficult to definitely conclude based on these tests whether the short-term depressed share prices show market overreaction or simply reflect the bear market. Regardless, returns for the scandal firms alone and all twenty-seven stocks over a one-year holding period are much greater than expected. These stocks managed to realize positive returns while the broader market was negative. By combining the selling short strategy and the contrarian strategy, returns of at least $10 \%$ were possible when the portfolio was held until one year following the scandal, no matter which stocks were bought (scandal firms vs. scandal firms and competitors) and no matter how long the stocks were sold short (one month or two months). This is impressive considering that the expected rate of return was $-5.04 \%$ for the scandal firms and -3.36 for all twenty-seven firms.

Overall, the returns when adjusted for outliers were similar to those that included the outliers. The second running of the data revealed that the share prices stayed down for longer than six months. Based on the results of this empirical study, the best trading strategy in response to scandal announcements appears to be one where the investor sells short the stock of scandal companies and their major competitors for two months. After those two months, the investor can form a portfolio with the same stocks they sold short and hold them until one year following the initial scandal announcement. If stocks react to future scandals in the same way they reacted during 2002 , then abnormal returns are possible. 


\section{CONCLUSION}

This paper has presented the hypothesis that the stock market overreacted to the accounting scandals of 2002, resulting in extensive decreases in share value among the scandal firms as well as their competitors. The theoretical foundation for this hypothesis lies in the Overreaction Hypothesis and the impact of investor psychology on financial markets. An empirical test of returns reveals that a strategy of selling short the scandal firms and their competitors, followed by a contrarian investment strategy of buying those same stocks, results in returns that were well above those expected for a period of one year after the scandal. The observed returns support the proposed hypothesis, exposing temporary market inefficiencies. Investors overreacted and over-generalized by selling shares of the competitors of scandal-tainted firms, perhaps intending to limit risk. Over the year following the initial scandal announcement, however, the overreaction was reversed, and positive returns were realized for the majority of firms included in this study. These findings support the Overreaction Hypothesis and refute the Efficient Market Hypothesis.

This paper has attempted to introduce a trading strategy that capitalizes on investor psychology and might be useful in response to future negative announcements. It is important to note that the market does become desensitized, and the market response from 2002 may not occur again, even if all the same factors were to repeat themselves. The corporate dishonesty of 2002 was shown through an overwhelming number of scandals, which undoubtedly caused increased risk awareness and heightened investor worries about additional problems. In the end, though, the stock market was not affected that greatly (although it did lose a few major players, such as Enron and WorldCom), and the fact that the market recovered is what investors will ultimately remember. If similar scandals happen in the future, investor reactions to them might not be as great. Even so, this study does reveal market inefficiencies and supports the power of investor psychology. There will always be major events in the future that lead to overreaction. It appears that using the strategies of selling short and contrarian investing in response to those negative news events may result in abnormal positive returns.

\section{REFERENCES}

1. Benou, G., Richie, N., 2003. "The Reversal of Large Stock Price Declines: The Case of Large Firms," Journal of Economics and Finance, 27, 19-38.

2. Conrad, J, Gultekin, M., 1997. "Profitability of Short-term Contrarian Strategies: Implications for Market Efficiency," Journal of Business and Economic Statistics, 15, 379-387.

3. Conrad, J., Kaul, G., 1993. "Long-term Market Overreaction or Biases in Computed Returns?" Journal of Finance, 48, 39-63.

4. $\quad$ De Bondt, W., Thaler, R., 1985. "Does the Stock Market Overreact?" The Journal of Finance, 40, 793805.

5. Dissaniake, G., 1997. "Do Stock Market Investors Overreact?" Journal of Business Finance and Accounting, 24, 27-49.

6. Forbes, W., 1996. "Picking Winners? A Survey of the Mean Reversion and Overreaction of Stock Prices Literature," Journal of Economic Surveys, 10, 123-158.

7. Hirschey, M., 2003. "Extreme Return Reversal in the Stock Market," Journal of Portfolio Management, 29, 78-91.

8. Hoover's Online: The Business Information Authority, available from http://premium.hoovers.com/subscribe/.

9. Jickling, M., 2003. “Accounting Problems Reported in Major Companies Since Enron,” Congressional Research Service, The Library of Congress: CRS Report RS21269. 
NOTES 